\title{
Eye, Matter and Interpretation
}

\section{Bente Larsen}

\begin{abstract}
A вsтRACт The main thesis behind the article is that Ad Reinhardt in his Abstract Paintings, through a 'painting away' of what traditionally constitutes painting, color, pictorial space and gesture, leads our attention towards visuality. The thesis shall be pursued through a discussion of two different approaches to visual sensing as aesthetic experience, one that prefaces a hermeneutical/phenomenological approach claiming sensuousness to unfold through the gesture of chiasm and 'intertwining', as it is formulated by Gottfried Boehm, and another, through Jean-Luc Nancy's post-phenomenological approach accentuating aesthetic experience as a gesture of distance. In the essay I shall focus on differences between the two and look into the question of how an implementation of a phenomenological chiasm and a hermeneutical claim for meaning in contrast to an epistemological and ontological focus on absence and the picture as Le distinc, leads to fundamental differences concerning the question of meaning, of interpretation.

KEY WOR DS Interpretation, Ad Reinhardt, Le distinc, post-phenomenology, Jean-Luc Nancy
\end{abstract}

Every sensory register ... bears with it both its simple nature and its tense, attentive, or anxious state: seeing and looking, smelling and sniffing or scenting, tasting and savoring, touching and feeling or palpating, hearing and listening. ${ }^{1}$

The differences between modes of sensing, that Nancy describes here, relate to sensing as such. There is, however, no doubt that art not only opens for a thematisation and realisation of these differences, art even stages and thematizes them. The main thesis of this article is that the American artist Ad Reinhardt's black abstract paintings from the 19506os epitomize this staging. My point of departure of the discussion will be that Reinhardt, in what I claim to be a painting set apart from what traditionally constitute painting, color, pictorial space and gesture, focuses/forces? our attention on the theme of visuality as such. The thesis shall be pursued through a discussion of two different approaches to visual sensing as aesthetic experience, one that prefaces a hermeneutical/ phenomenological approach claiming sensuousness to unfold through the gesture of chiasm and 'intertwining', as it is formulated by Gottfried Boehm, and another, through Jean-Luc Nancy's post-phenomenological approach accentuating aesthetic experience as a gesture of distance. Central to both approaches is the reciprocity of the relation between eye and object and an emphasis on the artwork as not only opening the eyes of the viewer, but of the artwork as looking back at you, addressing you, 
and even forcing you to look through an appealing gesture; a gesture that appeals through fascination. Furthermore, they share a view of art as a gestural event, just as the inseparability of form and content, the 'how' and the 'what', is essential to the way they approach the artwork. However, in this essay I shall focus on differences between the two and look into the question of how an implementation of a phenomenological chiasm and a hermeneutical claim for meaning in contrast to an epistemological and ontological focus on absence and the picture as Le distinc, leads to fundamental differences concerning the question of meaning, of interpretation. The point of departure of the discussion will be Ad Reinhardt's Abstract Paintings. ${ }^{2}$

Ad Reinhardt produced his completely black Abstract Paintings during the last years of his life from 1954 till his death in 1967, and from 1960 and onward they were given the same size which was $153 \times 153 \mathrm{~cm}$, all of them framed by a narrow wooden frame and divided into nine squares, barely noticeable, separated by very small nuances of black. In the production of the paintings Ad Reinhardt did not use black paint, but only the colors red, yellow, green and blue, colors that, when mixed, turn black. These colors were applied again and again, with one color being applied on a contrasting color and in transparent glaze technique. Thereby he not only painted away color, but also light. Furthermore, he painted away the surface quality of oil painting by adding turpentine to the paint, giving the paintings a velvet-like matt surface. This particular surface quality was underlined by grounding the canvas with a coating containing rubber. Finally, Reinhardt also painted away any traces of gesticulation. Most often he would place the canvas on a table and cover it with uniform brushstrokes, and at the same time covering traces of previous brushstrokes with new ones.

Through the apparent reduction of traditional visual and pictorial means, such as color, brushstrokes and composition, these paintings represent a challenge both to sensory experience and the art historical eye. Within art history and its emphasis on influences and progression, Ad Reinhardt never really fitted in and he has therefore been classified as either an outsider or a transitional figure between abstract expressionism on the one hand and minimalism and conceptualism on the other. ${ }^{3}$ In this classification, Ad Reinhardt's own texts, in which he defines his art as forming the 'end of art', have played a significant role. ${ }^{4}$ This interpretation has also inspired scholars to consider the black paintings to be a kind of "metaphysical transitions". Stephanie Rosenthal has, for example, determined the black canvases as "not quite", because of what she 
considers to be eternally prolonged transitions, not opening up for the viewer in the same way as the black paintings of abstract expressionists such as Frank Stella and Mark Rothko do. Instead, she claims that Ad Reinhardt closes the surface of his paintings, rejecting the viewer. ${ }^{5}$ In this she sees an equivalent to mysticism, referring to Ad Reinhardt's fascination with Zen Buddhism and close friendship with the mysticist Thomas Merton, who regarded darkness to be divine, because it made possible the transgression into a meditative stage of liberation from thought and feelings. ${ }^{6}$ Furthermore, the square shape of the 'black paintings' is also seen as a counterpart to the Mandela, which in the far-east was used as an object of meditation, symbolising the powers of the universe. This made Rosenthal conclude:

Like Mandela's, Reinhardt's works invite the viewer to meditate, on a calm pictorial structure from which the opposition of dark and light has been expunged - an equivalent of a mental and spiritual state in which the duality of all opposites has been overcome through the achievement of a state of pure being. ${ }^{7}$

The empty square as an age-old symbol of cosmos also plays an important role in Gottfried Boehm's interpretation of the 'black paintings'. But unlike Rosenthal's interpretation of the paintings as transitions, Boehm sees divinity unfolding in a dialectics of negation taking place within the picture. It is a dialectics in which the gesture of iconoclasm plays a central role formed by a reduction, by Boehm conceptualized as an "aufhendenden Substraktion", a process in which the painting is at the same time dissolved and kept. In this process Boehm's concept of Ereignis forms a central point. Ereignis implies a definition of the artwork as an event appearing processually ${ }^{8}$ and to look at [sehen] the picture is nothing but the realization of its immanent relations. ${ }^{9}$ This way the reality of the picture never is but takes place $^{10}$, it happens, and is at the same time created anew every time it is looked at. "The creation is not behind us, it takes place in front of our eyes." ${ }^{11}$ In this process the eye is pivotal: "The power of the picture implies: to make seen, to open the eyes. In short: to show [zeigen]."12 Only when the picture is seen does it exist. At the same time the picture is included in a phenomenological perceptual reciprocity. Not only does the eye open up for the picture, the picture makes you see, it looks back at you. Perception is part of the production of the work. This way the viewer and the artwork are intertwined in a chiasm: 
Theoretically it is a question of Chiasma. Pictures imply an immanent intertwining, a processual reflexivity, iconic contrast or iconic difference. Its moments take place, as a "play" between embodiment and reference [Verweisung], between materiality and impact or meaning, respectively. ${ }^{13}$

This implies both a momentarines of the process of perception, meaning that each time the art work is met is a unique meeting, and that this look of creation [hervorbringende Sehen] opens up a totally new world, different from the chaos of the real world in offering a new totality.

It is the need for overview, the desire to see totalities, to tell a story, to look at a picture, to listen to a melody: i.e. to begin and to end, and to link again the ending with the beginning. No matter how dissociated the artworks appear to us, they still want to be an integrated part of in our lives. ${ }^{14}$

It is to describe this emphasis on the artwork as unity formed by the inseparability of perceiver and perceived, of representation [Darstellung] and what is represented [Dargestelltem] that Boehm uses the concept of Ereignis. It is a unity that also forms both the basis of and preconditions a hermeneutic of visual art, as Boehm formulates it, taking the hermeneutics of Gadamer as his point of departure.

A key concept here is 'mimesis'. According to Boehm, Gadamer expands the concept of mimesis into implying recognition rather than simply imagining and informing. Recognition in that meaning transcends what is already known. To illustrate the relevance of hermeneutics also in relation to abstract paintings, Boehm claims that what these paintings make possible is an exploration of a visual order of sensuousness uncalculated within the matter of the picture, presenting evidence and outbidding any accidental blurring. According to Boehm, in Gadamar's hermeneutics this mimetic behavior is universalized into a category of cognition [Erkennens $].{ }^{15}$ This way cognition is independent of language and concepts, both when it comes to the approach of the artwork, and the artwork itself. To interpret, no translation into words of its content is called for, instead it is its sensuousness that we experience, a sensuousness that take part in what cannot be presented, in which the border between what is visible differs from and at the same time is intertwined into the invisible. ${ }^{16}$

Even though the picture this way invites a perception that differs from any other kind of perception, it does not stay isolated and self-sufficient. Instead Boehm maintains that a precondition of cognition is an opening up of the work to its other, to reality and intervention from reality. 
Without this, the aesthetic perfection of the work would do nothing but fascinate or seduce, Boehm underlines, and the work would not open up a world that the viewer recognizes and in which he or she recognizes herself. Thus, mimesis implies that the work allows for a real experience, because it endures the negation of abstraction, the unfamiliar and the opaqueness. "He, who experiences that, gains self-confidence, as he is faced with a new and possible world." ${ }^{17}$ Even if the work closes itself in its own world of abstraction, its raison d'être is this opening up a world, this intertwining of work and world, and of work and viewer. It is through this symbiosis of world, work and viewer that the artwork as well as the inclusion of its historical background that the work gains its meaningfulness as well as its theoretical and scientific relevance. The need to include historical analysis in the approach of the artwork must not and cannot be questioned, Boehm emphasizes. ${ }^{18}$

Emphasis on history and symbiosis is also what characterizes Boehm's approach to Ad Reinhardt's Abstract Paintings. Negation implies dialectics and the possibility of synthesis, and Boehm sees this dialectical movement [Aufhebung] emphasized in the way Ad Reinhardt's Abstract Paintings are produced, the way Ad Reinhardt literally painted away color and light. It is partly on the basis of this process that Gottfried Boehm determines the black paintings as materializations of what he calls "aufhebenden Substraktion", thereby forming a Hegelian dialectics of chromatic and luminous differences within the strong energy of the primary colors appearing through the consequent, changing and overlapping into a condition of tautological simplicity. ${ }^{19}$ Through this process of "Aufhebung" the painting is at the same time dissolved [Auslöschung] and kept [Aufbewahrung]. The black paintings unveil only a minimum of recollection of this process of difference to the patient viewer. Instead it leads him into the narrow edge [Grat] on which he sees a complex world of color perishing. And it is this moment of disappearance that the black paintings mediate. ${ }^{20}$ "A dawning abyss, in which all light is devoured, and from which it again occurs." ${ }^{21}$ It is this moment of going to the ultimate limit in the process of pictorial "Aufhebung" that Reinhardt has mediated. Not through presentation but through integration of the viewer into a black light, "that exposes him to the disappearance of light and the 'thicknesses of darkness." ${ }^{22}$ By interpreting what he considers to be the empty square of the black paintings as an age-old symbol of cosmos, Boehm convincingly conveys an interpretation of the black paintings as a spiritual resurrection. His points of departure are 'nachmachen' of the immanence of the processuality of the painting itself, phenomenological 
chiasm and the hermeneutic 'Verstehen' leading to a fruitful symbiosis of an approach to the artworks, maintaining sensuousness as well as cognition in the approach to artworks.

However, if we, instead of considering the 'thickness' or 'fullness' [Dichte] of the black as forming the basis of transgression, determine it as surface, dominated by grids, blocking the view, and if we instead of considering the black matter as a materialization of a dialectical process of 'Aufhebung', of dissolution and production, look at it as a vibration of nuances in black, put into effect by the nine squares being almost imperceptible, of indications of light and color vibrating in a process of disappearing and coming into existence, we open up for a different approach.

Being without narrativity or compositional dynamism, the pictures can be said to have reached a stand still through an elimination of time through the immanent neutralization of narration and dynamism. But, instead of time taking place within the painting, time is and must be incorporated into the mode of reception according to Yve-Alain Bois: "The only way to achieve timelessness was to fold time back on the spectator: what one sees in front of a "black" Reinhardt is the narrativization of one's gaze." ${ }^{23}$ This way the opticality of the pictures is transferred from the painting to the perceiver. Yve-Alain Bois describes Ad Reinhardt as "the least optical painter [...], yet at the same time he could be called the only such painter because he reduces the spectator to the sole organ of his or her vision." ${ }^{24}$ One reason for this displacing of time away from the picture to the viewer is, according to Bois, Ad Reinhardt's use of the grid. ${ }^{25}$ Bois claims that the use of the grid throughout the history of modernist painting was a key moment in the struggle against the arbitrariness of composition:

The power of the modular grid is that it is at once a deductive (centripetal) structure and an all-over (centrifugal) system. As such, it eliminates any notion of a final formal unity: this unity is given at the beginning, thus there is no struggle to achieve; it is not a reward. ${ }^{26}$

The picture as based on the unity of the surface/background opposition is leveled out forming instead an iconoclasm of pictoriality, an eclipse of pictorial narrativity and temporality that forces the attention away from the picture to the act of seeing. Allowing the gaze no place to rest within the picture, the picture returns the gaze, making the viewer and the act of seeing the focus of the picture. What now becomes the theme of the pictures is the act of seeing. It is an act that, in being determined by pictorial opacity, preconditions distance; an approach in which chiasm 
finds no anchor, opening instead a visuality of distance, of the touching eye, and not the absorbing eye, or the interpreting eye. This opens for a realisation of narrativity and the dialectics of absorption being replaced by the gesture of silence.

"Sense opens up in silence" Jean-Luc Nancy asserts in his small essay on listening, "It is indeed a question, and it must be a question till the end, of listening to this silence of meaning". ${ }^{27}$ An essential aspect of Nancy's post-phenomenological approach to the art work is an emphasis of the impenetrability of the image as le distinc. Nancy differentiates between Christian and sacred art. The gestural remark: Hoc est corpus meum, makes in the Christian paradigm something absent present by creating an incarnation of something that is without body. This way religion is the observance of a rite that forms and maintains a bond between the object and the viewer. Unlike the Christian image, the sacred image signifies what is set apart, removed, cut off. It forms no bond.

Where sacrifice ceases, so does religion. And that is the point where, on the contrary, distinction and the preservation of a distance and a "sacred" distinction begin. It is here, perhaps, that art has always begun, not in religion [...] but set apart. ${ }^{28}$

But art is more than distance, it is what is distinct, i.e. le distinc. Le distinc implies that the image is 'limitlessly' different from any worldly manifestations and exactly by being freed from a being of the world the image can be seen as a "pure" presentation of presentation. This foregrounding of separation and distance over phenomenal disclosure or presentation makes the image into a presentation (and withdrawal) of a distinct sense, which as distinct is separate or infinitely distant from any worldly manifestation, that is, withdrawn from a finite being-in-the world,

... what in the saying, is other than what is said, in a sense the non-said or silence, but still the saying itself, and even that telling silence [silence disant] like the space in which "I hear myself" when I grasp significations, when I hear them coming from the other of my thoughts. ${ }^{29}$

The distinct is formed both in relation of the artwork to its other, and within the work itself. Within the work the distinction takes place as a distinction between meaning and the materiality, or the 'thing' character of the work, within a sense that opens up in silence, in "the alterity of what is said" as Nancy quotes Lacan for saying. ${ }^{30}$

It is a reflection on distinction that is first formulated in Maurice Blanchot's differentiation between poetic and everyday language. What 
distinguishes poetic language is that it makes things disappear in the here and now of their presence, leaving poetic language as an authentic language allowing its own existence ${ }^{31}$. When the poetic language this way frees itself from its natural reality, it makes present the absence and discovers itself in contradiction to what it means. Only the work of art allows for this essence. Language and objects that function as exchange of information conceal this absence whereas the artwork demands that we experience this absence as absence. It does so not only by negating the reality of the thing in the word, but also by negating the concept to which the word refers resulting in the words not ending up in any ultimate referent or meaning, but in an absence that is claimed to be in the middle of language, opening for language as a language of silence. ${ }^{32}$

This language of silence Blanchot sees materialized in the poetics of Mallarmé, describing the authenticity of his language as formed by a destructive energy, a power to transpose 'the thing' into its 'near disappearance.. ${ }^{33}$ In his analysis of Manet, Bataille opens for a realisation of how this process of silencing and absence can take place within pictorial art. According to Bataille, it was Manet that finally settled the score with rhetorical painting and paved the way for the painting we know today, and the means were the negation of the object as representation, i.e. the thing, and what he called the empty use of past forms. "Silence de l'art" was the means. ${ }^{34}$ According to Bataille the object is nothing but an overwrought vibration of negation in the thing, independent of any meaning. Through a process he calls 'opération', he claims that Manet brings the objects into silence. One example is L'Exécution de Maximilien (1867). The way, in which Manet has depicted the scene, the title of the painting and its narrative, are of no importance. Instead, Bataille claims, it is because Manet has chosen a theme that is loaded with meaning, that the effect of painting it without feeling, without affection, becomes stronger. Therefore, the silence in this painting is definitive. Bataille compares it to the anesthetization of the nerves at the dentist: you know that the pain is there, but you do not feel it, and you are not supposed to feel it. It is through this denial of compassion by means of a destruction of content, through the striping of the paintings of convention by the use of 'l'attente décue $^{\prime 35}$ that Manet, according to Bataille, formulates the distinction between 'immediate' and 'essential language'. ${ }^{36}$ Bataille here opens for the modernist emphasis on 'the how' as conditioned by the destruction of the significant 'what' of immediate language and the 'thing'. To Blanchot and Bataille this silencing was necessary in order to reach the 'essential' poetic language. 
In Ad Reinhardt's black painting the immediacy of time and narrative are silenced by the grid, displacing time from an event taking place within the painting to the viewer and by the gesture of painting away painting itself by means of silencing colour and painterly gesticulations. Gesture is no longer the gesture of authentic expressiveness, but the gesture of silence. Through this silencing the black paintings have become a matter of sensing, of the awareness of sensing. Attention is forced back into the very act of looking, changing focus away from the interpretation of immanent pictorial narratives to the very act of looking. Nancy puts it this way:

Painting doesn't make itself seen in the same way as everything else that we can see. It makes itself seen as a reversal of seeing, as the ability to deceive all sight, in order to make us see precisely the opposite: not what we see, but the fact that it is seen. ${ }^{37}$

However, without some kind of appeal, some kind of fascination, this reversal cannot take place. In Nancy's emphasis of the impenetrability of the image as le distinc, in which the gesture of the eye is the gesture of the touching eye as an instant of 'proximity-in-distance' a "plaisir du geste" is a precondition. This way, the definition of painting as le distinc assumes an approach of desire and fascination. Vision to Nancy is an opening of the visible. It is always less a matter of seeing than of that which, from the inside of the painting itself, pushes to be seen, enters and penetrates the eye turning vision into a matter of touch ${ }^{38}$, a tactile seeing that can penetrate into the very place of desire. The pleasure of gesture is not the pleasure of the complete and perfect, but of what begins, what opens up. This way desire is less turned towards the object than towards its power, its potentialities. It is turned towards attraction (élan), birth, beginning. Not beginning as a point of departure, but as truth as the form that forms, its creation. It is not a question of a metaphysics of silence but of a silence opening up for the resonant subject:

\footnotetext{
"Silence" in fact must be understood not as a privation but as an arrangement of resonance: a little - or even exactly.... - as when in a perfect condition of silence you hear your own body resonate, your own breath, your heart and all its resounding cave. It is a question then, of going back from the phenomenological subject, an intentional line of sight, to a resonant subject, an intensive spacing of a rebound that does not end in any return to self without immediately relaunching, as an echo, a call to that same self. ${ }^{39}$
}

The silence that Nancy opens for through the post-phenomenological 
touching eye is the silence determined by the intimate forces of the art work. These forces are not represented by the image, but the image is them, it extracts them by withholding them, and it is with these forces that the image touches us. It touches us as poetry that has become the matter of the image. "For the image is always material, it is the matter of the distinct, its mass and its density, its weight, its edges and its brilliance, its timbre and its spectre, its pace and its step, its gold" 40

The modernist claim for an essential and poetic language, put forward by Blanchot and Bataille and recognized in the art of Mallarmé and Manet, has in Nancy's post-phenomenology become a question of materiality, opening for an understanding of Ad Reinhardt's Abstract Paintings as a poetics of painterly material through a distillation of what forms the essence of this language, the material reality of painting as being tied together with the eye as sensing, the eye as seeing the seeing, as it is formulated by Derrida:

For if our eyes see what is seeing rather than visible, if they believe that they are seeing a gaze rather than eyes, at least to that extent as such, they are seeing nothing, then, nothing that can be seen, nothing visible. Away from all visibility, they founder in the night. ${ }^{41}$

Through the very gesture of silencing as a gesture of distinction, of withdrawal and intensity, the eye has become the touching eye not the penetrating eye, or the eye searching for meaning. By opening up a reflection on painting as the process of making itself seen, not only as painting, but as an opening into a reflection on seeing Nancy also opens for an approach to the black paintings as not only thematising seeing, but epitomising a staging of seeing as a gesture of silence through distance and conditioned by fascination.

To conclude, to both Boehm and Nancy the particularity of visual sensuousness is of pivotal importance. However, when it comes to the actual approach to the artwork and in the end how they define the artwork, the differences between the two are telling. At the same time as Boehm maintains that cognition of images is independent of language and concepts he still emphasises the need for interpretation. The world that the artwork opens for is a world of an intertwining of world, work and viewer and through the inclusion of the historical background the work gains what Boehm decribes as its meaningfulness. In his interpretation of Ad Reinhardt Boehm thus ends up with a concluding interpretation of the black paintings as a symbol of cosmos. The processuality of negation of painting as 'Aufhebung' is resolved in spiritual resurrection. 
If we instead of making an interpretation of Ad Reinhardt's black paintings as a dialectical opening of a transition into cosmos, focus on the aspect of silence as part of his poetics, i.e silence as a silencing of painterly immediacy, different implications of the black paintings emerge. The going back from the phenomenological subject, as Nancy describes it, ${ }^{42}$ allows for a space of intensity, of the silence that conditions the resonance of the body, of the senses, a space turning vision into a touch resonating the gesture of pleasure and fascination. Instead of being a dialectics of negation it is a gesture of infinite incompletion ${ }^{43}$ opening for a realisation of the senses.

\section{Notes}

1. Jean-Luc Nancy, Listening (Fordham: Fordham University Press, 2007), 5.

2. While Gottfried Boehm explicitly has discussed Ad Reinhardt, the same is not the case with Jean-Luc Nancy, therefore the post-phenomenological interpretation of Ad Reinhardt's 'black paintings' is totally on my account.

3. One example is Douglas Crimp taking the opacity of the surface of the $A b$ stract Paintings, as his point of departure, and the absence of illusionistic space, Crimp sees a similarity to minimalism, but ends up concluding that Ad Reinhardt in his use of rectangles creates the same pictorial space already seen in cubism or constructivism and that he therefore first of all is a transitional figure between abstract expressionism and minimalism. Douglas Crimp, "Opaque Surfaces", in Minimalism, ed. James Meyer (New York: Phaidon, 2005), 257-63. Another voice in this historicist tradition is Michael Corris, who claims that Ad Reinhardt, through his texts he is a producer of cultural meaning in the same way as the conceptual artists. Michael Corris, Ad Reinhardt (London, Reaktion Books, 2008), 130.

4. Lucy Lippard, for example, concludes: "Any discussion of Modernist monotone painting must emphasize the central role of Ad Reinhardt, whose square, black, symmetrical and almost invisibly trisected paintings are, according to him, 'the last paintings that anyone can paint' [...]. By denying color in his black paintings from 1960 on (though some of them still retain traces of the extremely close-valued red, blue and green with which they began), Reinhardt has simply taken his steadfastly art-for-art's sake to its logical end." Lucy Lippard, "The Silent Art", in Minimalism, ed. James Meyer (London, Phaidon, 2000), 229-30.

5. Stephanie Rosenthal, Black Paintings (München: Hatje Cantz, 2006) 75

6. Thomas Merton, "New Seeds of Contemplation", in Joseph Masheck, "Five Unpublished Letters from Ad Reinhardt to Thomas Merton and Two in Return", Art Forum, (1978), 23-27, cit. from Stephanie Rosenthal, Black Paintings (München, Hatje Cantz, 2006), 41. 
7. Stephanie Rosenthal, Black Paintings (Munich: Hatje Cantz, 2006), 42.

8. Gottfried Boehm, "Hermeneutische Reflexion und bildende Kunst", in Gottfried Boehm, Wie Bilder Sinn erzeugen: Die macht des zeigens (Berlin: Berlin University Press, 2007), 245.

9. Gottfried Boehm, "Die Bilderfrage", in Was ist ein Bild?, ed. Gottfried Boehm (Munich: Wilhelm Fink Verlag, 1994), 335.

10. "Die Werke sind Metaphern, eine Realität die nie ist, die sich in Fluss befindet", ibid.

11. "Die Schöpfung liegt nicht hinter uns, sie geschieht soeben, vor unseren Augen", ibid.

12. "Die Macht des Bildes bedeutet: zu sehen geben, die Augen zu öffnen. Kurzum: zu zeigen." Gottfried Boehm, "Anmerkungen zur Logik des Bilder", in Wie Bilder Sinn erzeugen: Die macht des Zeigens, ed. Gottfried Boehm (Berlin: Berlin University Press, 2007), 39.

13. "Bildtheoretisch gesprochen haben wie es mit einem Chiasma zu tun. Bilder implizieren eine innere Verschränkung, eine prozesshafte Reflexivität, ikonischen Kontrast oder ikonische Differenz. Ihre Momente 'spielen' zwischen Verkörperung und Verweisung, zwischen Materialität und Wirkung bzw. sinn." Gottfried Boehm, "Auslöschung - Aufhebung - Negation", in Wie Bilder Sinn erzeugen: Die macht des Zeigens, ed. Gottfried Boehm (Berlin: Berlin University Press, 2007), 59.

14. "Es ist das Bedürfnis nach Überblick, es ist das Lust Totalitäten zu sehen, eine Geschichte zu erzählen, ein Bild zu betrachten, eine Melodie zu hören: d.h. zu beginnen und zu enden, das Ende mit dem Anfang wieder zu verknüpfen. So disparat uns künstlerische Werke entgegenkommen, sie wollen in unsere Lebenserfahrung integriert sein", Gottfried Boehm, "Der erste Blick. Kunstwerk - Aesthetik - Philosophie”, in Die Aktualität des Ästhetischen, ed. Wolfgang Welsch (Munich: Fink, 1993), 369.

15. Boehm, "Hermeneutische Reflexion", 266.

16. Gottfried Boehm, "Læren om billedforbudet”, Terskel, no. 7 (1992), 152.

17. Boehm, "Hermeneutische Reflexion", 267.

18. Boehm, "Hermeneutische Reflexion", 266.

19. Boehm, "Ikonoklasmus", 65.

20. Boehm, "Ikonoklasmus", 66.

21. "Ein dämmernder Abgrund, der alles Licht verzehrt, aus dem es sich aber auch meldet." Boehm, "Ikonoklasmus", 66.

22. "...ihn einem schwarzen Licht, dem Schwund der Hellligkeit und der Dichte des Dunkels aussetzt." Boehm, "Ikonoklasmus”, 6.

23. Yve-Alain Bois, "The Limit of Almost", in Ad Reinhardt (New York: Rizzoli, 1992), 28. 
Bente Larsen

24. Yve-Alain Bois, "The Limit of Almost", 28.

25. See Rosalind Krauss, "Grids", in The Originality of the Avant-Garde and Other Modernist Myths (Cambridge, Mass.: MIT Press, 1985), 9-22.

26. Yve-Alain Bois, "The Limit of Almost", 19.

27. Nancy, Listening, 26.

28. Jean-Luc Nancy, "The Image - the Distinct", in Jean-Luc Nancy, The Ground of the Image (New York: Fordham University Press, 2005), 1-2.

29. Nancy, Listening, 29.

30. Nancy, Listening, 29.

31. Nancy, Listening, 29.

32. See furthermore the dicsussion on Blanchot and the litterary work undertaken by Ullrich Haase, in Blanchot and Litterary Criticism (London: Continuum, 2001).

33. Nancy, Listening, 29.

34. Georges Bataille, Manet (Paris: Skira, 1994), 42.

35. Bataille, Manet, 25-47.

36. Bataille, Manet, 19.

37. Jean-Luc Nancy, "Interviews", in Jean-Luc Nancy, Multiple Arts: The Muses II (Stanford: Stanford University Press, 2006), 161.

38. See also Jacques Derrida, On Touching: Jean-Luc Nancy (Stanford: Stanford University Press), 2005.

39. Nancy, Listening, 21.

40. Nancy, "The Image”, 12.

41. Derrida, On Touching, 2.

42. Nancy, Listening, 21.

43. On gesture as the infinite incompletion of the already-unmade, see John Paul Ricco, "The Separated Gesture or, The Inoperative Praxis of the AlreadyUnmade", paper for Keynote lecture presented at Gesture: The 2013 Annual Conference of the Nordic Society of Aesthetics, Oslo, June 1, 2013. 